PUBLICATION 1412

what you should know about

SEEDS

530.4

$\mathrm{C} 212$

P 1412

Rey.

1990

$O O A$

C.3
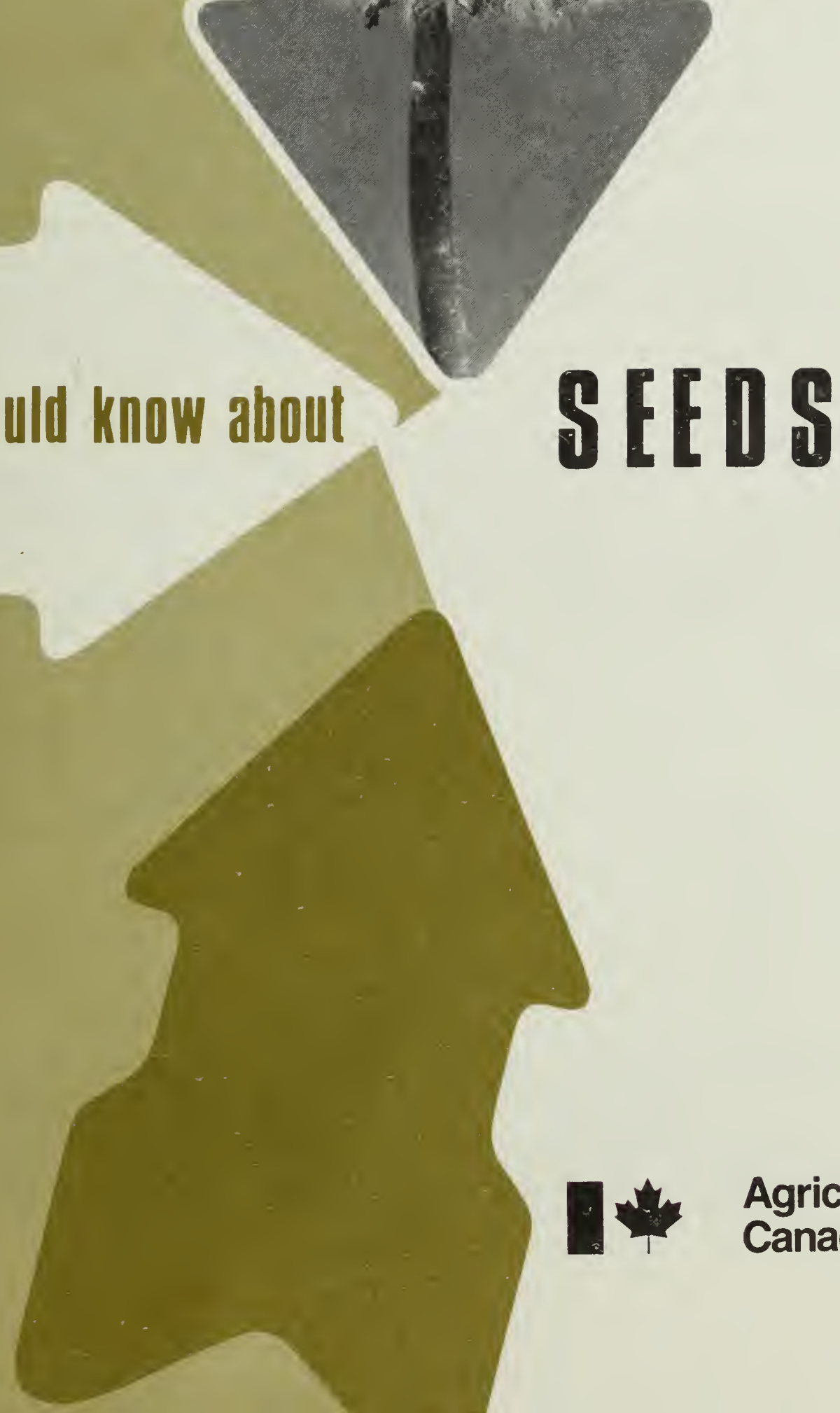

Agriculture Canada 
PUBLICATION 1412, available from

Information Services, Agriculture Canada, Ottawa K1A OC7

CMinister of Supply and Services Canada 1980

Cat. No. A53-1412/1980E ISBN: 0-662-11095-1

Printed 1970 Revised 1980 6M-9:80

Aussi disponible en français

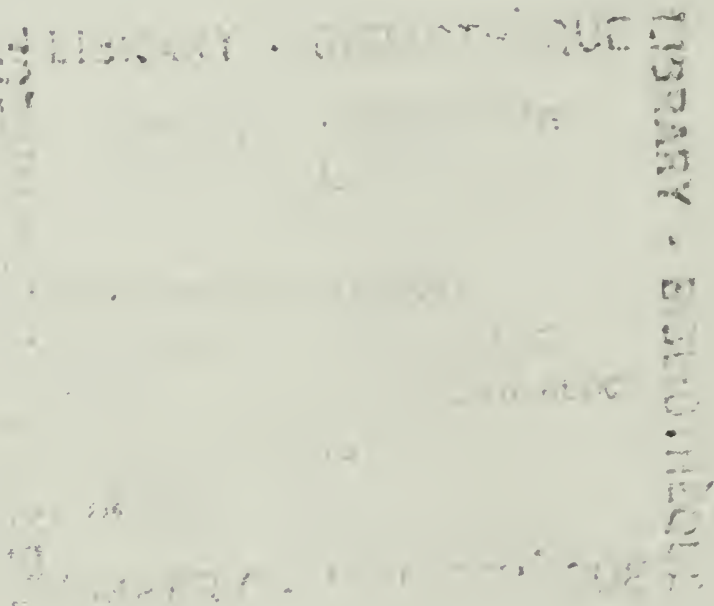




\section{WHAT YOU SHOULD KNOW ABOUT SEEDS}

A seed is really a young plant in the resting or dormant stage. It is the means by which a plant reproduces itself at a later time when conditions are suitable. In other words, seeds are the beginning of a new generation in the life of a plant.

Most seeds consist of three main parts:

- The embryo is a tiny plant inside the seed. It is often called the germ.

- The endosperm is the food reserve for the growing embryo.

- The pericarp is the seed coat. It protects the embryo and endosperm from damage.

The embryo inside the seed is very much alive. When conditions are favorable it will germinate and produce a plant. Close examination of a seed embryo reveals one or more miniature leaves (cotyledons), a short stem and a small root. Plants that have two seed leaves, such as peas and beans, are called dicotyledons, whereas those with a single seed leaf, such as corn, are called monocotyledons.

The endosperm, or food reserve, usually makes up the larger part of a seed. It provides the new plant with food until its own roots are well developed and working. In some seeds, food reserve is found in the seed leaves, for example, peas, beans, tomato and watermelon seeds.

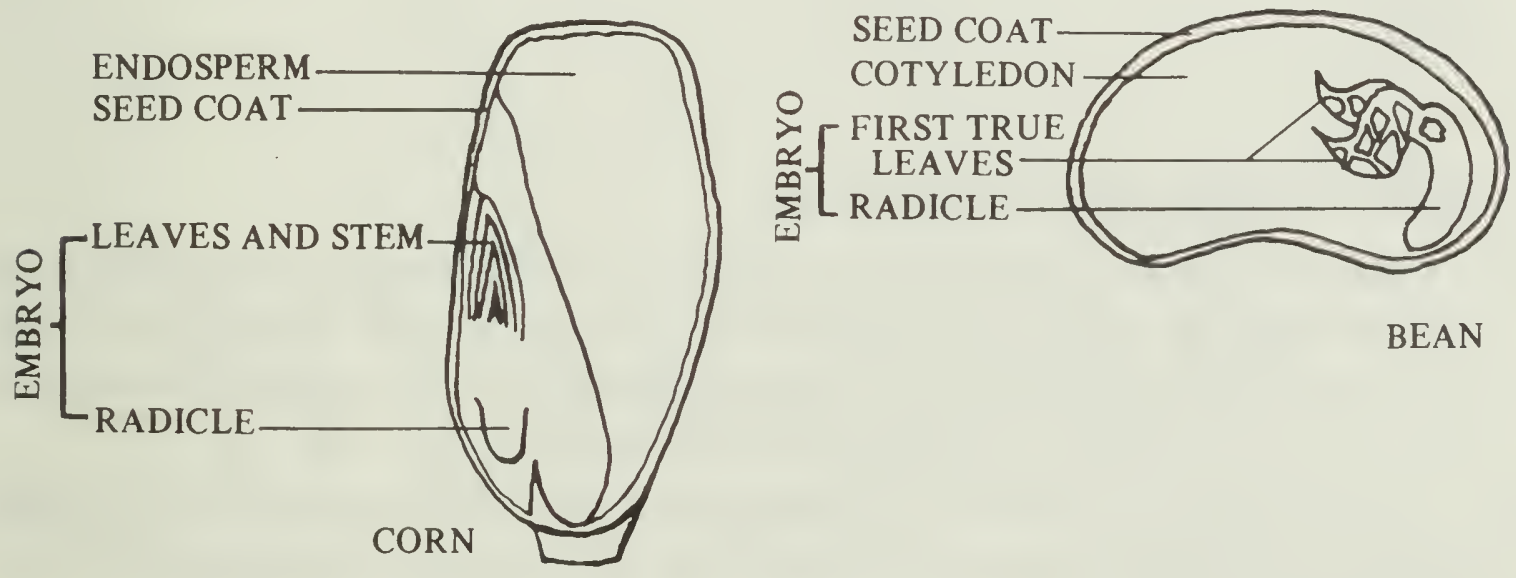

\section{VALUE OF SEEDS}

The endosperm and cotyledons of most seeds are rich sources of food for humans and animals. They contain carbohydrates, proteins and lipids.

Carbohydrates in seeds are mainly sugars and starches. Wheat, rye, barley and oats have a high content of carbohydrate which provides energy food for man and animals. 
Proteins are necessary for growth in man and animals. They are nitrogencontaining compounds manufactured by plants. Soybeans and peanuts are excellent sources of this food component.

Lipids are mostly fats and oils. Seeds of flax and sunflowers contain a high percentage of oil.

\section{NUTRITIVE VALUES OF COMMON SEEDS}

$\begin{array}{lccr}\text { Seed crop } & \text { Protein } & \text { Carbohydrate } & \text { Oil } \\ & \% & \% & \% \\ \text { Barley } & 12 & 66 & 2 \\ \text { Corn } & 9 & 71 & 4 \\ \text { Flax } & 24 & 24 & 36 \\ \text { Oats } & 12 & 58 & 4 \\ \text { Peas } & 23 & 57 & 1 \\ \text { Peanuts } & 30 & 12 & 48 \\ \text { Rapeseed } & 20 & 16 & 44 \\ \text { Rice } & 8 & 65 & 2 \\ \text { Rye } & 12 & 71 & 2 \\ \text { Soybean } & 38 & 25 & 18 \\ \text { Sunflower } & 16 & 18 & 26 \\ \text { Wheat } & 13 & 70 & 2\end{array}$

\section{Seeds as Food for Humans and Animals}

Man grows and harvests great quantities of seeds to be used as food for himself and his livestock. Wheat, a cereal belonging to the grass family, provides more food for humans than any other plant. The second most important seed grown by man is rice. It is used as food by a third of the world's population.

Corn, barley and oats are the three most important seeds grown for feeding livestock in Canada. Great quantities of these and other grains are grown wherever farm animals are raised.

\section{Processed Seed Products}

Seeds are used to make a wide variety of food products and other materials. For example, wheat can be processed into flour, starch, breakfast food and macaroni; corn can be converted to starch, breakfast food, oil and syrup. Certain seeds, notably sunflower, flax, rapeseed and soybeans, are grown mainly for their oil which can be used to make margarine, salad and cooking oils, paints and lubricants. Seeds of the coffee tree, cocoa palm and many other trees, herbs and grasses are processed for beverages, spices and drugs. 


\section{HOW SEEDS ARE PRODUCED}

Many plants, as they grow and mature, produce flowers which in turn yield a seed crop. Most plants have perfect flowers, containing both male and female parts, but some species produce male flowers on one plant and female on another. A few plants, such as corn, have both male and female flower parts on the same plant but in different locations.

Male flowers have stamens (filaments and anthers) and produce pollen grains (male cells). Female flowers have pistils (stigma, style and ovary) and produce egg cells. The seeds are produced when the male cells from the pollen grains unite with egg cells, or ovules, in the ovary. This process is called fertilization.

The means by which the pollen grains reach the pistils varies greatly. For some plants, wind is the principal carrier of pollen grains from the male to female flowers. Notable examples are corn, and maple and pine trees. With many other plants, insects are necessary for the transfer of pollen from one flower to another. To attract pollinating insects such as honeybees, many plants have brightly colored petals or sepals and produce a sweet secretion called nectar. As the insects go from flower to flower collecting this nectar, pollen grains are transferred from the stamens of one flower to the pistil of another. Insect pollinators are essential for seed (and fruit) production of a great many crops such as cucumber, melons, cherries and oranges, and beehives are often placed in orchards and fields to increase the insect population.

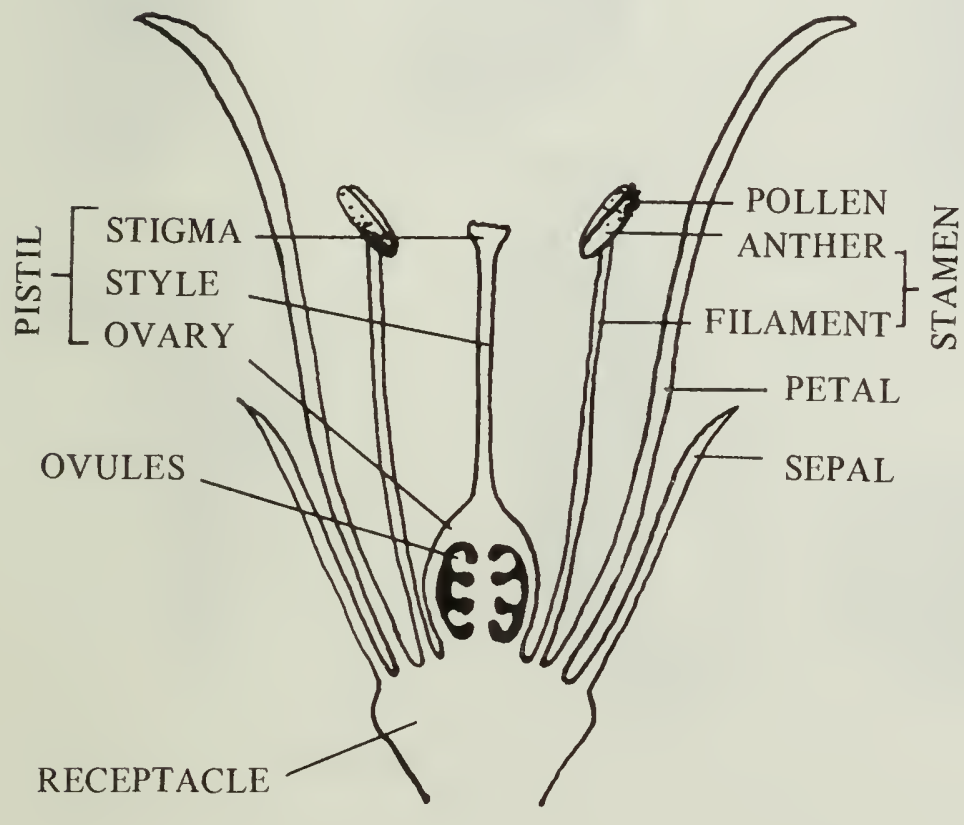

STRUCTURAL PARTS OF A FLOWER

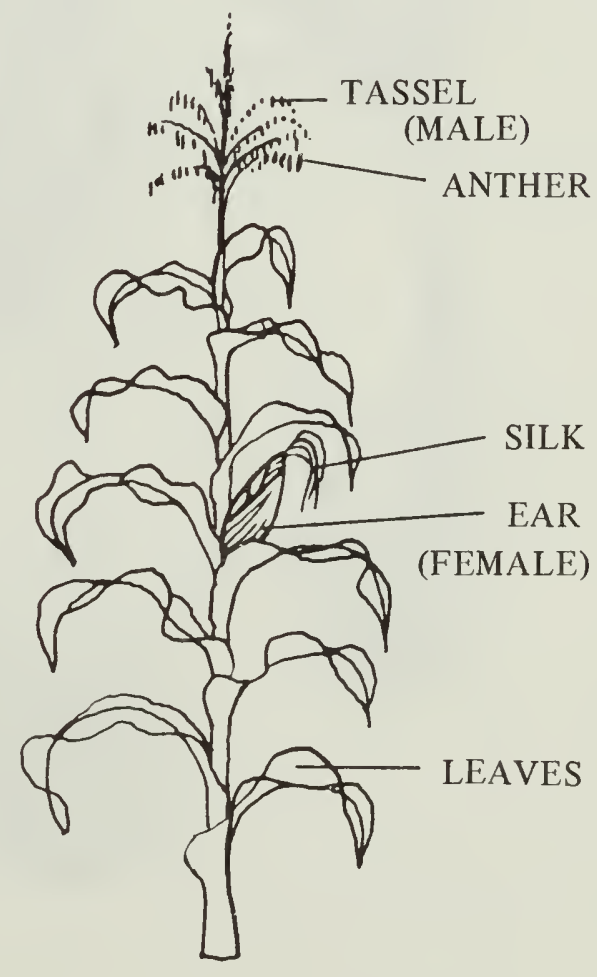

CORN PLANT 


\section{Kinds of Seeds}

There are about 250000 different seed-bearing plants in the world today. Each has its own kind of seed, which can be identified by its size, shape and color.

Size: Seeds vary in size from the dust-like seeds of begonias and orchids to that of the double coconut palm whose seed often weighs as much as $18 \mathrm{~kg}$.

Shape: The range in the shape of seeds is amazing. Many seeds are round, spherical, oval or oblong in shape. Some are elongated, flattened, curved or squared with all possible shapes in between.
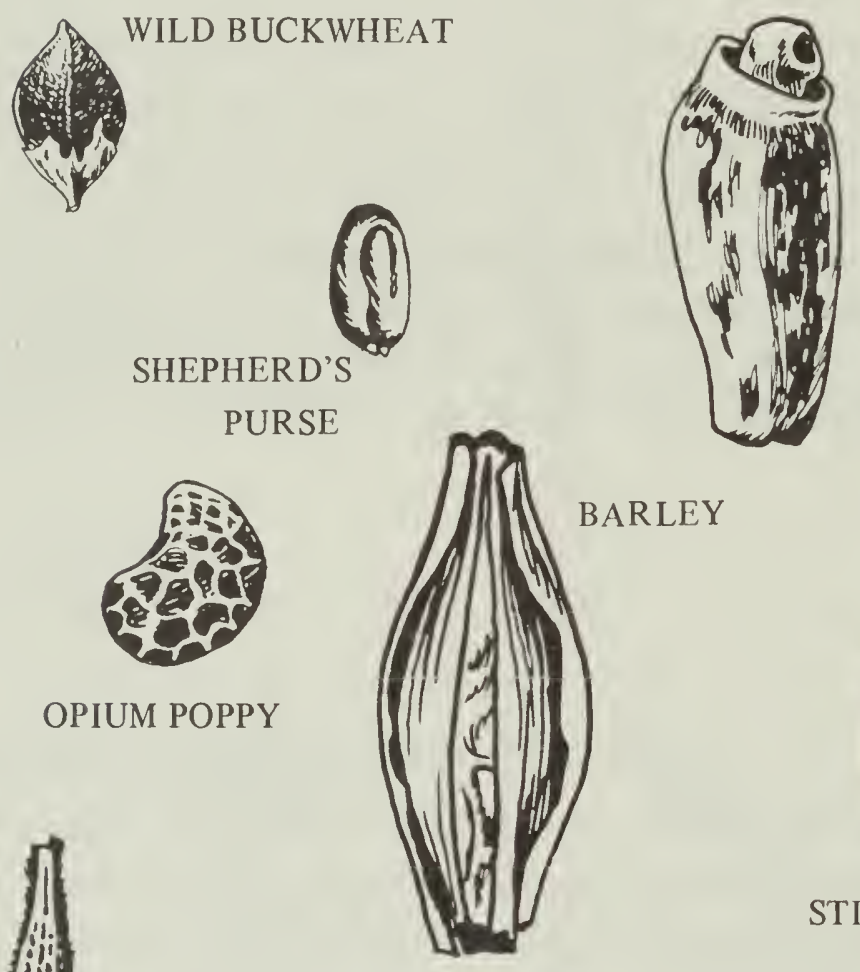

FIELD MADDER

MILK THISTLE

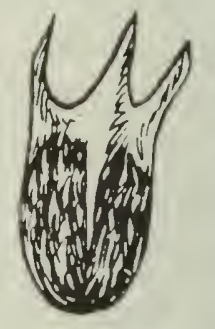

CAT'S EAR
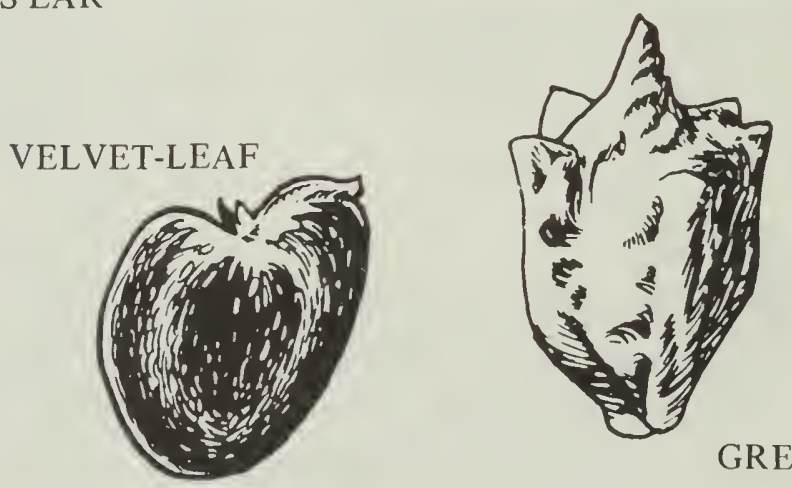

OX-EYE DAISY

GREAT RAGWEED

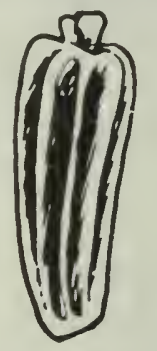


Color: The color of seeds varies from snow white to jet black with all colors of the rainbow in between. In some seeds, the color is solid or uniform; in others, two or more colors may form a design or an irregular pattern. Also, the seed coat may appear dull or highly glossy, hard or soft, thick or thin, and with all possible combinations of these characteristics. Furthermore, seed surface can be smooth, pitted, pebbled, ridged or wrinkled, and a surprising number have attached structures or appendages to make them more interesting.

Truly, a large seed collection can be just as fascinating as a stamp collection.

FORKED CATCHFLY

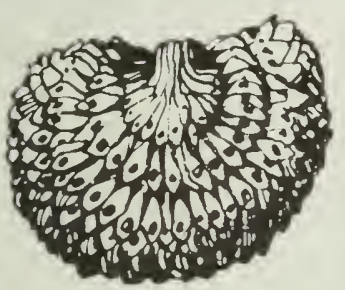

SCOTCH THISTLE
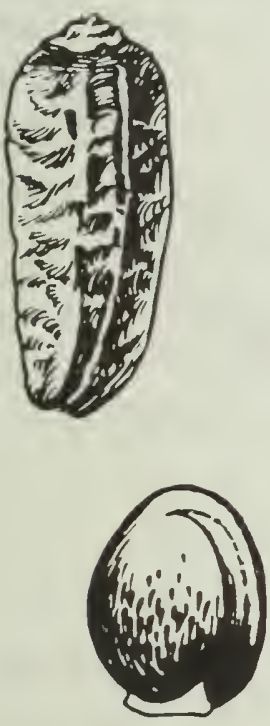

ERUCA

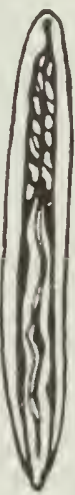

GREAT

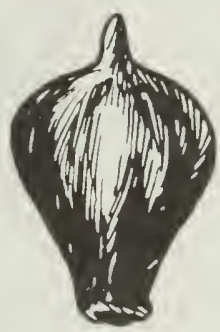

BULRUSH

\section{WILLOW-HERB}

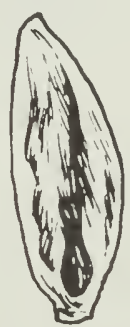

WILD RICE

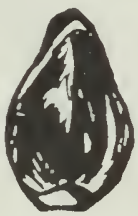

FORGET-ME-NOT

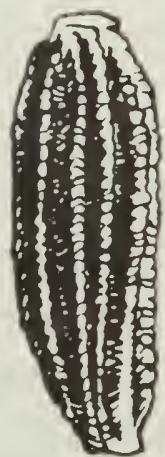

SOW THISTLE

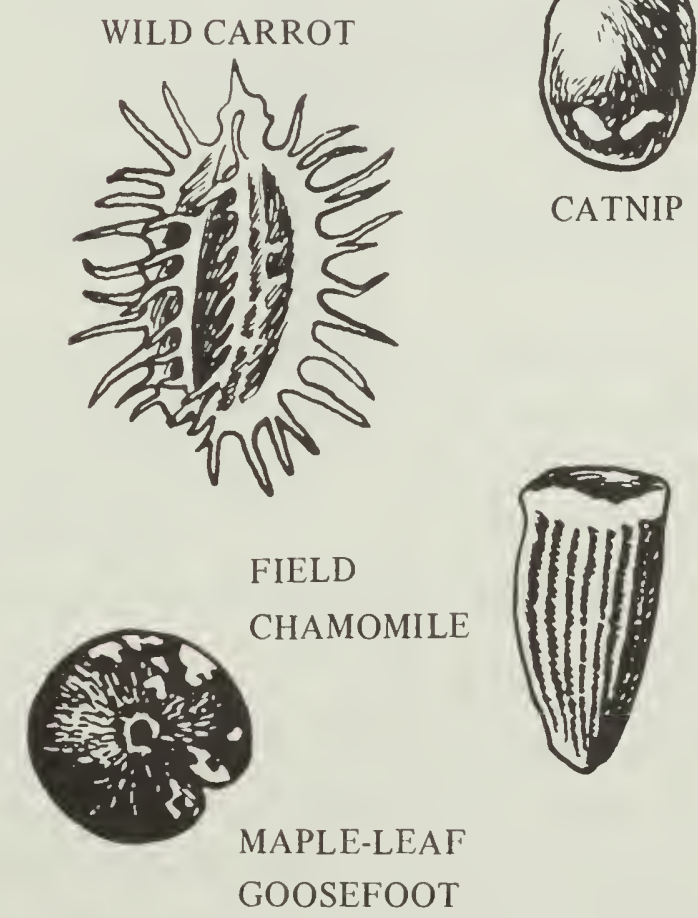



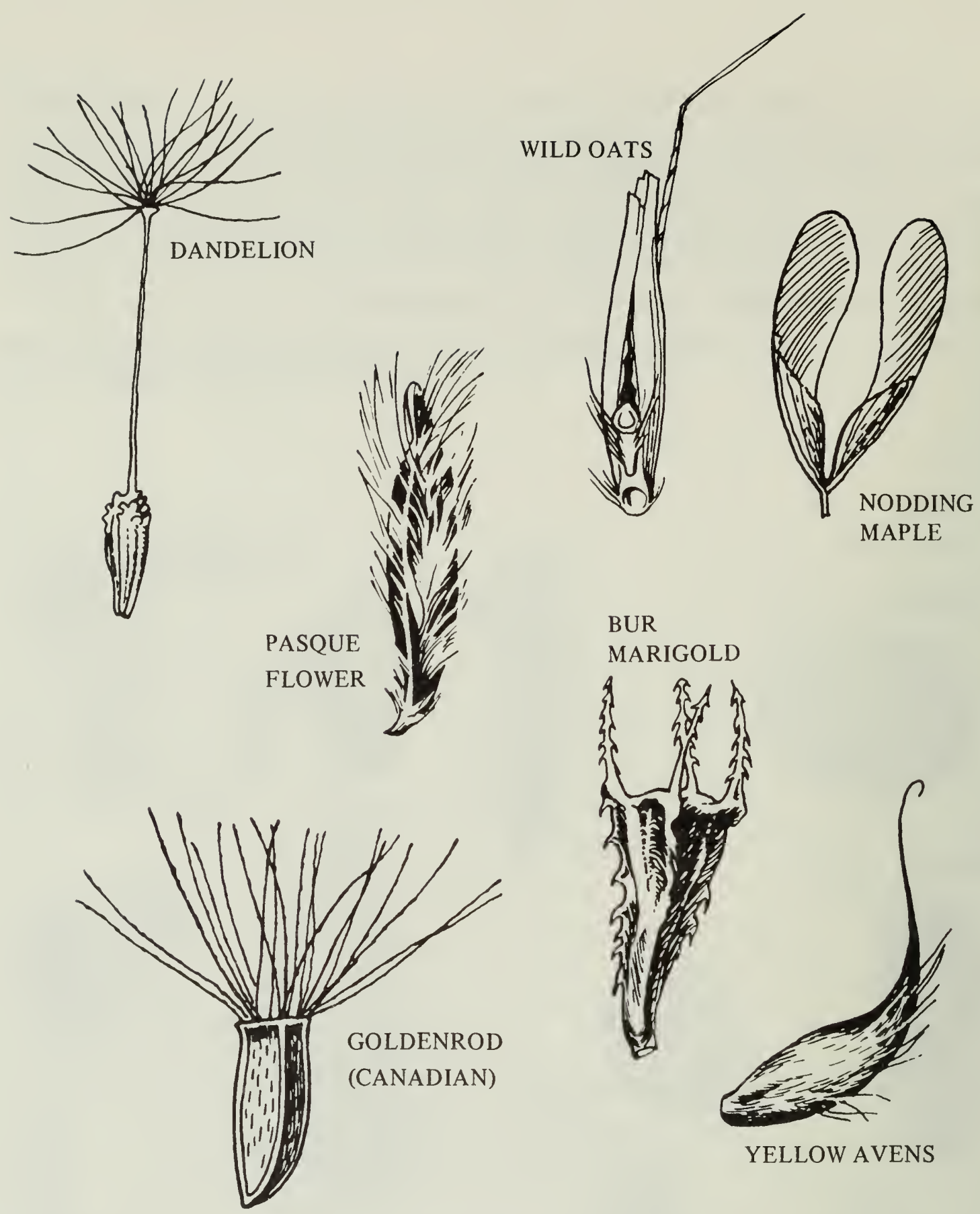

\section{HOW SEEDS SPREAD}

Associated seed structures such as hairs, bristles, spines, hooks, knobs and wings help to spread seeds over great distances. Seeds of beggarticks, blue burr and burdock are well knows to anyone who has walked through a native field or a bush. The umbrella, or parachute, of the dandelion or milkweed is equally well known. The winged seed (samara) of maple and other trees assists in spreading the species. Of particular interest is the flaxseed, which develops a gelatinous covering when wet and becomes glued to whatever it touches. The wild oat seed can drill itself into the soil when its bristle (awn) becomes wet. A number of seeds can pass unharmed through the digestive system of animals and birds and may thus be dropped many miles away. 


\section{SEED NUMBERS}

Some plants produce only one or two seeds. Most plants, however, produce a few dozen, a few hundred, or even a few thousand seeds. A large tumbling pigweed can produce millions of seeds! As a result, soil may contain a surprisingly great number of seeds. For example, a scientist in California found more than 2.8 billion seeds in 0.4 ha of soil.

\section{SEED LONGEVITY}

Live lotus seeds from a dried-out lake in northern Asia are believed to be over 1,000 years old. This is an example of great seed longevity. Under normal conditions, seeds are relatively short-lived. Willow and poplar seeds live only a few weeks, but many other seeds remain alive from 3 to 15 years, and some considerably longer. Farmers know for a fact that seeds of wild oats, mustard and other weeds can remain alive in the soil for a very long time.

\section{SEED GERMINATION}

Some seeds, such as those of the silver maple, will germinate and grow as soon as they fall into moist soil. Others require a long resting period before growth can begin, even though conditions are ideal. This rest period guarantees that seeds will not germinate out of season. The rest period may last a few weeks, a few months or several years, depending on the kind of seed. Sometimes this after-ripening process can be speeded up by repeated freezing and thawing.

Most seeds, especially crop seeds, begin to grow soon after they are planted in a moist, warm soil. Each kind of seed has its own requirement and preference for moisture, temperature, air and light.

- Moisture: The need for moisture is universal and is the first requirement for seed germination. Some seeds require very little moisture for germination; examples are spinach and cabbage seeds. Other seeds, such as those from rice and cattails, must be completely submerged in water. Seeds with waterproof seed coats will germinate only if the seed coat has been scratched (scarified) and water allowed to seep in.

- Temperature: When moisture is sufficient, the next most important requirement for germination is a suitable temperature. Corn and beans germinate best at warm temperatures $\left(22^{\circ} \mathrm{C}\right.$ to $\left.31^{\circ} \mathrm{C}\right)$, whereas wheat and peas prefer cooler temperatures for germination and growth.

- Air: Plants and seeds, like animals, require oxygen to maintain life. Seeds sown too deep, especially in heavy clay soils, do not germinate because they lack oxygen. As a general rule, the smaller the seed, the more shallow it should be sown. 
- Light: Most seeds germinate best in the dark. Some weed seeds will germinate only when brought to the surface after being buried for months or years. On exposure to sunlight, they soon start to grow.

The germination process consists of the active growth of embryos. The first sign of germination is an increase in the size of the seed as it absorbs moisture. Then the root tip breaks out of the softened seed coat and, as it grows, pushes down into the soil. Finally, the growing tip with young leaves emerges from the seed, pushing up towards the soil surface.

During this early growth stage, the young plant derives its food from the seed's cotyledons or endosperm. Soon, the root system starts to function and it obtains nutrients from the soil. At the same time, the leaves become functional and convert these nutrients to food for plant growth.

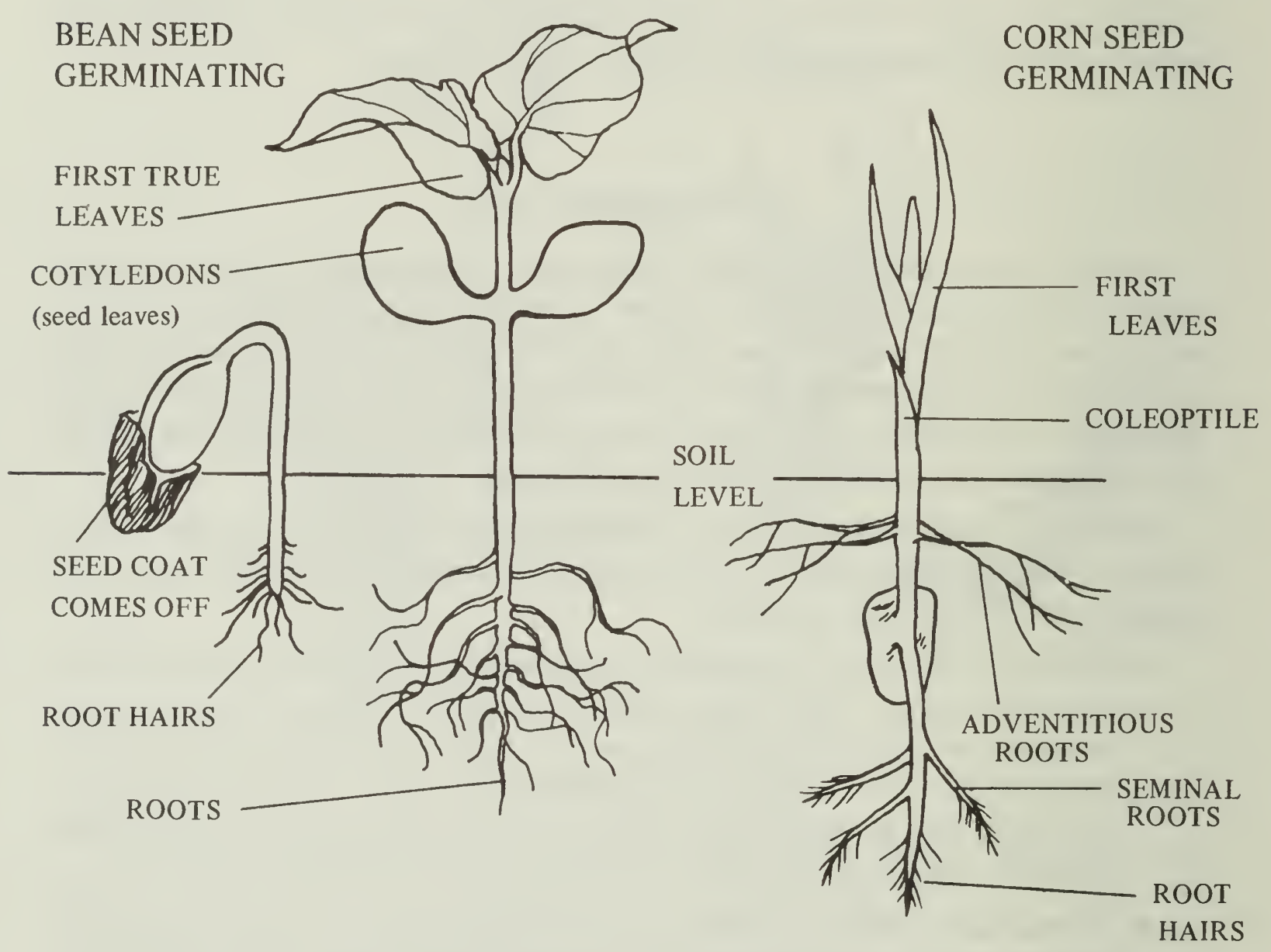

\section{SEED INSPECTION AND CERTIFICATION}

Seeds are subject to diseases and injury just like plants and animals. To protect seed buyers, Agriculture Canada is responsible for administering the Canada Seeds Act which regulates the importation and sale of seeds in Canada. The Canada Seeds Act requires that seeds offered for sale be labeled as to kind, variety, grade and 
name and address of seller, and that they meet the standards of purity, germination and general quality of the grade indicated.

The Canadian Seed Growers' Association is the official pedigree-granting agency in Canada and is responsible for maintaining pedigree records and granting pedigree status to seed crops. In cooperation with inspectors of the Department's Plant Products and Quarantine Division, the C.S.G.A. ensures that seed produced under the pedigree system is related to original Breeder stock.

Canada's system of seed production is held in high regard throughout the world and has been copied, wholly or partly, by many countries.

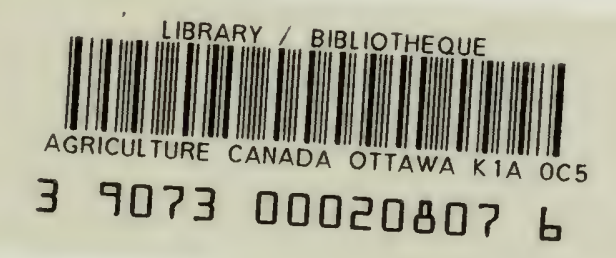


